\title{
Legal Framework of Orbital Transportation Services: US Experience
}

\author{
Ivanna Nepyivoda \\ Ph.D. Student, Yukhymenko Family Doctoral School \\ of the National University of Kyiv-Mohyla Academy \\ (Kyiv, Ukraine) \\ E-mail: ivannanep@gmail.com
}

\begin{abstract}
Space law is a set of laws that regulate activity in space, covering domestic and international agreements, rules and principles. Research and use of space resources in the majority is a collective activity , which involved dozens of countries. It is the interstate associations that are able to provide financial, intellectual and technological conditions for expanding human activities beyond the boundaries of the planet. One of the promising directions of space exploration is the commercial orbital transportation services. The Ukraine Space Agency is a worthy partner in various inter-state associations specializing in the development and provision of cargo transportation to the low-Earth orbit. It is for this reason that the introduction of new approaches in the US legal framework of cargo transportation services to the low-Earth orbit is of considerable interest to Ukrainian science. Analyze the legal framework of commercial orbital transportation services in the United States is the purpose of paper. The author describes the activities of NASA's "Commercial Orbital Transportation Services» program, which implements a strategy for the development of transport capabilities of private companies.
\end{abstract}

Keywords: space law; NASA; commercial space industry; orbital transportation services.

\section{Правове забезпечення орбітальних транспортних послуг: досвід США}

\section{Непийвода, Іванна Василівна}

аспірантка Докторської школи імені родини Юхименків, Національний університет «Києво-Могилянська академія»

(Київ, Україна)

\begin{abstract}
У статті досліджуються правові аспекти комериійних послуг із транспортування на навколоземну орбіту за законодавством США. Розглянуто становлення відповідної моделі публічно-приватного партнерства за участю НАСА та систему правового регулювання загальних питань закупівель у комериійній космічній галузі для потреб НАСА. Висвітлено діяльність програми НАСА «Комериійні послуги з орбітального транспортування», яка впроваджує стратегію розвитку транспортувальних спроможностей приватних компаній. Проаналізовано особливості
\end{abstract}

(C) Nepyivoda, Ivanna, 2018 
договорів про партнерство порівнюючи з традиційними договорами НАСА, які трунтуються на Федеральних правилах закупівель. Обгрунтованою, щь договори про партнерство є оптимальним правовим інструментом для иієї мети.

Ключові слова: космічне право; НАСА; комериійна космічна галузь; орбітальне транспортування.

Received: January 28, 2018; accepted: March 3, 2018

Advanced Space Law, Volume 1, 2018: 66-73.

https://doi.org/10.29202/asl/2018/1/8

\section{Вступ}

Одним із напрямків діяльності Національної адміністрації з питань аеронавтики і космосу (HACA; National Aeronautics and Space Administration, NASA), незалежної інституції у складі федерального уряду Сполучених Штатів Америки, є проекти, пов’язані 3 Міжнародною космічною станцією (МКС) [NASA: 2017]. Змога доставляти на станцію і зі станції значні обсяги вантажів (обладнання, припасів і, щонайважливіше, членів екіпажу) - неодмінна передумова для такої діяльності. Ця проблема ставала дедалі гострішою внаслідок поступового згортання програми космічних човників після катастрофи ракетоплану «Колумбія» 2003 р., аж до її цілковитого закриття 2011 р. Із часом додався ще один чинник - прагнення звести нанівець залежність від співпраці з Росією, яка забезпечувала транспортування значної частини вантажів на станцію [Hackler, 2014: 19].

Постало конкретне завдання - запропонувати й упровадити новий спосіб транспортування, що задовольняв би вимоги надійності й безпечності, водночас істотно знизивши вартість таких операцій [Partnership, 2015]. У зв'язку з цим значний інтерес для юридичної науки й практики становить впровадження у США нових підходів до правового забезпечення комерційної діяльності із транспортування вантажів на навколоземну орбіту.

Метою статті є аналіз правових аспектів комерційних послуг із транспортування вантажів на навколоземну орбіту за законодавством США.

\section{Результати дослідження}

Із прагнення скоротити державні видаткив в США розвинувся ще один складник завдання - на відміну від попередньої практики НАСА вирішило відмовилася від купівлі ракет-носіїв. Натомість вона мала намір допомогти дібраним комерційним компаніям налагодити послуги з транспортування вантажів на навколоземну орбіту, а потім сама ж купувати ці послуги. Закон про комерційну космічну діяльність (1998 р.) встановлює, що комерційні послуги 3 космічного транспортування належить набувати як комерційну річ. Це дало підстави фахівцям НАСА провести аналогію своєї концепції із тим, як клієнт передає пакунок кур'єрові служби доставки. Інший образний приклад купувати авіаквиток, а не самий літак [Hackler, 2014: 12].

Такий підхід у загальних рисах мав прецедент в американській історії. Близькі за своєю природою правовідносини було встановлено на основі закону 1925 p. (Contract 
Air Mail Act), який заохочував комерційну авіацію, дозволивши Поштовій службі США укладати контракти з приватними компаніями. І від самого заснування НАCA 1958 p. приватні компанії були причетні до їі діяльності як підрядники, а з 1980-х адміністрація почала активно шукати шляхи залучення приватного сектора до поточних космічних операцій [NASA, 2014].

Загальне правове підгрунтя для будь-яких комерційних закупівель НАСА сформувала низка правових актів. Відповідно до Закону про комерційну космічну діяльність федеральний уряд набуває (acquire) космічні транспортні послуги від комерційних надавачів США у тому разі, коли такі послуги потрібні в процесі його діяльності. Як «комерційного надавача США» цей закон розглядає компанію, понад $50 \%$ якої володіють громадяни США, або філію іноземної компанії за умов, які встановлює Міністр транспорту [Lindenmoyer, 2014: 104]. До інших важливих документів належить Політика США з космічного транспортування (2005 р.), яка наголошує на використанні ракет-носіїв виготовлених у США; Національна космічна політика (2006 р.), що заохочує розбудову комерційної космічної галузі; та Акт стримування Ірану, Північної Кореї та Сирії, який обмежує закупівлі російських космічних систем для потреб МКС [Lindenmoyer, 2014: 105].

Принципове рішення про перехід до послуг з космічного транспортування від комерційних надавачів ухвалено в середині 2000-х. Однак складність полягала в тому, щоб утілити цю ідею в життя, оскільки на той час не існувало якихось готових зразків чи конкретних настанов щодо взаємодії державних структур із приватними компаніями в такий спосіб [Partnership, 2015]. Насамперед це потребувало належного правового забезпечення.

Організаційно вирішення завдання вилилося у створення в структурі НАСА в листопаді 2015 р. Управи комерційної програми щодо екіпажів і вантажів (Commercial Crew and Cargo Program Office, С3РО) [Hackler, 2014: 110]. До іiі завдань належало впроваджувати політику США щодо освоєння космосу; сприяти приватній американській промисловості у показі своїх спроможностей з транспортування вантажів і екіпажів на навколоземну орбіту в безпечний, надійний та ощадливий спосіб; творити ринкове середовище, в якому комерційні космічні транспортні послуги доступні для держави і клієнтів приватного сектора [Commercial, 2012]. Управа провадила три пов'язані між собою програми [Lindenmoyer, 2014: 107]:

1. Програма «Комерційні послуги з орбітального транспортування» (Commercial Orbital Transportation Services, COTS), що опікувалася питання проектування, розробляння, випробування й добору приватних ракет-носіїв. А вже на основі ії результатів функціонують дві інші програми:

2. Комерційні послуги з постачання (Commercial Resupply Services, CRS), яка власне й забезпечує транспортування вантажів для потреб МКС;

3. Комерційна еволюція екіпажу (Commercial Crew Development (CCDev) — заміна екіпажів зі станції, яка послуговується тим правовим механізмом, що й COTS.

У цьому випадку НАСА застосувала двоетапний підхід до придбання транспортних послуг для МКС. Мета COTS полягала в тому, щоб заохотити комерційних партнерів у їх конструкторській діяльності й дати змогу показати свої спроможності ще до процесу закупівель. Натомість CRS є програмою незалежної закупівлі послуг, які вже наявні на ринку [Commercial, 2015]. Отже, урешті-решт HACA мала забезпечити для компаній, що успішно показали свої спроможності у межах COTS, перехід до договорів про операційні послуги, притаманних для CRS [Lindenmoyer, 2014: 109]. 
Підходи до договірних відносин, які застосували COTS i CRS, істотно різняться. CRS цілковито покладається на процедуру укладання договорів із постачальниками на основі давно опрацьованих і чинних Федеральних правил закупівель (Federal Acquisition Regulation). Для належного контролю Правила закупівель вимагають, щоб усі договори містили певний стандартний набір положень, зумовлюють можливість використовувати кошти лишень цілком згідно з умовами договору, передбачають складну бюрократичну процедуру звітування і перевірки виконання [Lindenmoyer, 2014: 107]. У разі невиконання своїх зобов'язань, постачальники зазнають відповідальності, у тім числі штрафних санкцій. Проте застосовувати такий підхід для COTS було б недоцільно, оскільки це аж ніяк не сприяло б ініціативі приватних компаній. Аби обрати оптимальні правові інструменти для досягнення мети COTS, тобто щоб дати змогу компаніям розвивати свої технології, уникаючи водночас усталених вимог і нагляду з боку НАСА, передбачених у стандартних контрактах про закупівлі, працювала група правників у галузі закупівель, інтелектуальної власності та комерційного права. На основі аналізу наявних правових норм вони випрацювали підхід до регулювання цих правовідносин, застосовуючи зважену новизну, не виходячи за межі чинного законодавства, зокрема Competition in Contracting Act of 1984 [Hackler, 2014: 19].

Принципово важливим було питання, до якого типу зарахувати правочини, які укладатимуть в межах програми COTS, тому що це визначало, норми яких саме правових документів слід застосовувати. Оскільки НАСА не набуває товар чи послугу для своєї безпосередньої вигоди, це не була закупівля у розумінні згаданих правил. Та й сама природа правочину в межах COTS інша - замість придбання товару чи послуги, НАCA допомагає промисловості розвинути послуги з транспортування на навколоземну орбіту [Hackler, 2014: 19]. Водночас це не даток (грант) або ж угода про співпрацю як у випадку, коли НАСА фінансує дослідження університетів на підставі відповідного закону (Federal Grant and Cooperative Agreement Act of 1977) [Lindenmoyer, 2014: 107].

Найкращим правовим інструментом для надання фінансових і технічних ресурсів приватним компаніям виявився «договір на основі Закону про космос» (Space Act Agreement, SAA), грунтований на «повноваженні щодо інших правочинів» (Other Transaction Authority, OTA). Цим повноваженням НАСА, першу серед усіх і одну з небагатьох федеральних інституцій, було наділено на підставі Національного закону про аеронавтику і космос (1958 National Aeronautics and Space Act). Суть повноваження полягала у праві укладати й виконувати широкий спектр правочинів, «які потрібні для іiі роботи», не керуючись вимогами Федеральних правил закупівель. Первісною причиною таких майже всеосяжних повноважень було прагнення сприяти успіхові в «космічних перегонах» із Радянським Союзом часів Холодної війни [Hackler, 2014: 20].

Для спрощення й надання гнучкості процесові придбання послуг, щоб наростити транспортувальні потужності комерційної космічної галузі НАСА скористалася таким своїм повноваженням і згодом уклала низку договорів на основі Закону про космос у межах програми COTS [Partnership, 2015]. Найдоцільніше їх назвати «договори про партнерство» (partnership agreements). Контрагентом НАСА тут є не постачальник чи підрядник, а партнер. Проте не існувало попереднього досвіду застосування такого різновиду договорів. Тому згадана група правників ретельно опрацювала всі їхні аспекти, зокрема й питання, які дозволяють виразно провести межу між діяльністю на підставі договорів про партнерство і закупівлями на основі відповідних федеральних правил [Hackler, 2014: 20]. 
На першій стадії, у межах COTS, НАСА обрала для себе статус інвестора, технічного консультанта й партнера (тобто не мала наміру купувати товари й послуги) замість статусу державного клієнта, який сплачує всі кошти на виконання замовлення й винагороду постачальникові [Lindenmoyer, 2014: 105]. Найперша мета договорів про партнерство заохотити комерційну космічну галузь розвивати й показати свої інноваційні й ощадливі можливості космічного транспортування, тобто їх укладають для демонстрації можливостей, а не для придбання товарів і послуг [Lindenmoyer, 2014: 106]. Більшість умов договорів про партнерство свідомо були пристосовані для цілком конкретної мети - посилити природу цих правочинів як зорієнтованих на комерційний розвиток, щоб зробити співпрацю привабливою як для НАСА, так і для приватних компаній [Partnership, 2015].

Договори про партнерство уможливили для НАСА залучення різноманітних комерційних партнерів. Однією з цілей COTS було дати змогу малим або щойно започаткованим підприємствам взяти участь у конкурсах HACA поряд із групою великих компаній, які посідають панівне становище на полі контрактів у космічній галузі [Hackler, 2014: 22]. Як і в більшості фінансових інвестицій у цьому випадку також немає гарантії успіху. Проте в перспективі урізноманітнення інвестиційного портфеля підвищує шанс позитивних наслідків. Тому стратегія НАСА полягала в тому, аби зрівноважити великі визнані компанії, з якими пов'язаний нижчий технічний ризик, із малими, які мають вищий ступінь технічного ризику, але, ймовірно, запропонують значно нижчі ціни. Загалом, забезпечуючи загальні принципи державних закупівель (справедливий розподіл замовлень і суворий контроль за витрачанням коштів), договори про партнерство спростили процедуру набуття послуг і скоротили пов'язані з нею витрати як для держави, так і для комерційних партнерів [Lindenmoyer, 2014: 107].

Зменшення кількості й обсягу вимог до контрагентів заохочує інновації та скорочує витрати HACA на відповідні перевірки. Зазвичай НACA накладає на постачальників великий обсяг розлогих технічних вимог. У випадку складної космічної системи їх кількість вимірюється тисячами. Дотримання вимог НАСА ретельно перевіряє. Це забезпечує щонайвищу якість, але потребує великих витрат часу, робочої сили й коштів 3 боку HACA, а також гальмує інновації компаній-партнерів. Тому в межах COTS обмежилися доволі коротким переліком найважливіших показників, які мусить задовольняти запропонована техніка, поклавши відповідальність за опрацювання дрібніших конструкторських рішень і перевірку якості на компанії-партнерів. Компаніям дозволено оптимізувати свої системи щоб краще пристосувати їх до власних бізнесових потреб, не порушуючи основних вимог. Виняток становлять лишень вимоги, пов'язані із безпекою МКС і способами подавання інформації (interface requirements), які НАСА регламентує $\mathrm{i}$ контролює відповідно до звичному порядку. Але в будь-якому разі тепер кількість вимог становить сотні, а не тисячі [Lindenmoyer, 2014: 108]. Щобільше, договори COTS не лишень дозволили компаніям продавати свої ракети-носії іншим потенційним покупцям, але й заохочують їх до цього. Це докорінна різниця від попередньої практики договорів, коли вся система була спрямована на те, щоб лишень НАСА і тільки вона володіла й могла використовувати вироби.

Однією з найцікавіших рис договорів про партнерство $є$ те, що вони дозволяють «еволюцію» системних вимог щодо проектованих виробів без потреби щоразу вносити відповідні зміни в тексти договорів і витрачати пов'язані із супроводом цих змін додаткові кошти. Зазвичай НАСА повсякчас аналізує й оцінює систему на предмет ії відповідності до деталізованих проектних вимог. Однак у договорах про партнерство вона встановлює тільки основні показники замовленої системи, а компанія може вільно впроваджувати інновації й оптимізувати систему. НАСА лишень спостерігає за процесом проектування, 
аби пересвідчитися, що систему побудовано й випробувано відповідно до вимог договору. Навіть у вимоги щодо безпеки й способу подання інформації за обопільною згодою сторін було внесено понад 70 змін, без будь-яких додаткових витрат з боку НАСА. У випадку звичайних контрактів досягнути такої гнучкості навряд чи було б можливо без відповідних додаткових витрат з боку НАСА [Lindenmoyer, 2014: 107].

Уклавши договір про партнерство, НАСА погоджується сплатити компанії-партнерові наперед визначену максимальну суму, тобто встановлено відомий і обмежений фiнансовий ризик [Lindenmoyer, 2014: 106]. Однак договір передбачає цілу серію (зазвичай близько двадцяти із щоквартальною періодичністю) проміжних стадій виконання договору, так званих віх (milestones). Са́ме задоволення вимог, встановлених віхами, $\epsilon$ єдиною підставою для сплати відповідної частки коштів на користь компанії із боку НАCA та подальшого тривання договору. На відміну від традиційних договорів партнери можуть отримати плату від НАСА лишень за умови виконання вимог, встановлених у віхах. Однак якщо компанія їх не виконала, НАCA має з'ясувати причину збою і встановити, чи якісь додаткові зусилля щоб домогтися виконання $є$ в інтересах держави. Відставання з виконанням віх не спричиняє розірвання договору в тому разі, коли НАCA дійде висновку, що досягнуто істотного поступу [Lindenmoyer, 2014: 106].

Важливою ознакою договорів про партнерство $є$ доповнення капіталу, якого вкладає в проект НАСА, інвестиціями, надходження яких забезпечує компанія. Це істотно різнить їх від звичайних договорів, у яких замовник сплачує всі кошти на виконання замовлення й винагороду постачальникові. Договори про партнерство прямо передбачають, що НАСА не може бути єдиним джерелом коштів. Важливим критерієм добору $\epsilon$ готовність і спроможність компанії зробити внесок у фінансування проекту. 3 іншого боку, саме певність у серйозності намірів НАСА в майбутньому придбати послуги конкретної компанії визначає іiі спроможність залучати кошти на фінансових ринках. Загалом, внесок компаній у проекти дуже істотний - він вимірюється сотнями мільйонів доларів [Lindenmoyer, 2014: 106].

Розмір внеску НАСА у втілення проекту встановлено заздалегідь, ще до підписання договору. А це означає, що саме на компанію, а не на НАCA, лягає тягар перевитрати коштів на будь-якій стадії проекту. Ще один важливий аспект: оскільки встановлено і фінансові віхи, то в разі, якщо компанія не залучить достатніх коштів 3 приватних джерел, договір може бути розірваний ще до того, як НАСА вкладе в цей проект значні кошти. Отже, в такий спосіб фінансовий ризик розподіляється, НАСА має вихід, якщо партнер виявиться неспроможний надати свою частку капіталу. Наприклад, у жовтні 2007 p. НАСА розірвала договір про партнерство на суму 207 млн. дол. із компанією Rocketplane Kistler лишень за рік після його укладення, оскільки компанія не змогла залучити обсяг коштів, який передбачав договір [Lindenmoyer, 2014: 108].

Щоб заохотити приватні інвестиції договори про партнерство також передбачають дуже обмежені можливості для їх розірвання з ініціативи HACA [Partnership, 2015]. Tрадиційні договори часто містили положення про розірвання договору з міркувань доцільності (a termination for convenience clause), що фактично дозволяло НАСА робити це на власний розсуд і з будь-яких міркувань. Натомість стаття 17 договорів про партнерство наводить вичерпний перелік підстав розірвання договору: спільна згода; невиконання умов з боку компанії; причини, що не залежать від НАCA, як от надзвичайні ситуації національного рівня, оголошення війни, невиділення потрібних коштів з боку Конгресу [Hackler, 2014: 22]. Якщо ж держава змушена односторонньо розірвати договір, вона несе фінансову відповідальність у розмірі, що не перевищує суму виплат у межах на- 
ступної віхи [Lindenmoyer, 2014: 108].

У межах програми COTS запуски космічних кораблів не провадить держава. Тому вони підпадають під ліцензійне регулювання Федеральної авіаційної адміністрації, яка відповідно до закону має сприяти підприємницькій космічній діяльності. Це з одного боку звільняє НАСА від передзапускового нагляду, а з іншого - готує компанії до подальшого надавання космічних транспортних послуг відповідно до правил Федеральної авіаційної адміністрації [Lindenmoyer, 2014: 108].

Загалом, програма COTS, яка закінчилася 2013 р., стала успішною. Ця модель публічно-приватного партнерства, проторувавши шлях для послуг приватних компаній із космічного транспортування, розпочала нову еру в комерційній космічній діяльності [Lindenmoyer, 2014: 109].

\section{Висновки}

Договори про партнерство є правовою основою для заохочення діяльності приватних компаній у цій сфері та пошуку найкращих партнерів НАСА. Вперше залучивши послуги приватних компаній із космічного транспортування НАСА було вирішено завдання із забезпечення Міжнародної космічної станції. Це незаперечний успіх і модель для майбутньої публічно-приватної співпраці. Надавши нового імпульсу космічній галузі США, вони становлять значний інтерес для науки космічного права і практики.

\section{Література}

Commercial Crew and Cargo Program Office (C3PO). National Aeronautics and Space Administration. April 27, 2012. https:/www.nasa.gov/offices/c3po/home/ c3po_goal_ objectives.html

Commercial Orbital Transportation Services (COTS). National Aeronautics and Space Administration. October 22, 2015. https://www.nasa.gov/commercial-orbitaltransportation-services-cots

Hackler, Rebecca. Commercial Orbital Transportation Services: a new era in spaceflight. Houston, Texas: National Aeronautics and Space Administration, Lyndon B. Johnson Space Center, 2014.

Lindenmoyer, Alan. COTS Model for NASA Public-Private Partnerships. Commercial Orbital Transportation Services: a new era in spaceflight. Houston, Texas: National Aeronautics and Space Administration, Lyndon B. Johnson Space Center, 2014: 103-109.

NASA 2018. Strategic Plan. 2017. https://www.nasa.gov/sites/default/files/atoms/files/ nasa_2018_strategic_plan.pdf

NASA Releases COTS Final Report. National Aeronautics and Space Administration. June 3, 2014. https://www.nasa.gov/content/nasa-releases-cots-final-report

Partnership for Public Service. Linking NASA and the private sector to further space exploration. The Washington Post. January 22, 2015. https://www.washingtonpost.com/ politics/federal_government/linking-nasa-and-the-private-sector-to-further-spaceexploration/2015/01/22/d022b34e-a24b-11e4-9f89-561284a573f8_story.html?utm term $=.91 \mathrm{a} 5087 \mathrm{f} 748 \mathrm{~b}$ 


\section{References}

Commercial Crew and Cargo Program Office (C3PO). National Aeronautics and Space Administration. April 27, 2012. https:/www.nasa.gov/offices/c3po/home/ c3po_goal_ objectives.html

Commercial Orbital Transportation Services (COTS). National Aeronautics and Space Administration. October 22, 2015. https://www.nasa.gov/commercial-orbitaltransportation-services-cots

Hackler, Rebecca. Commercial Orbital Transportation Services: a new era in spaceflight. Houston, Texas: National Aeronautics and Space Administration, Lyndon B. Johnson Space Center, 2014.

Lindenmoyer, Alan. COTS Model for NASA Public-Private Partnerships. Commercial Orbital Transportation Services: a new era in spaceflight. Houston, Texas: National Aeronautics and Space Administration, Lyndon B. Johnson Space Center, 2014: 103-109.

NASA 2018. Strategic Plan. 2017. https://www.nasa.gov/sites/default/files/atoms/files/ nasa_2018_strategic_plan.pdf

NASA Releases COTS Final Report. National Aeronautics and Space Administration. June 3, 2014. https://www.nasa.gov/content/nasa-releases-cots-final-report

Partnership for Public Service. Linking NASA and the private sector to further space exploration. The Washington Post. January 22, 2015. https://www.washingtonpost.com/ politics/federal_government/linking-nasa-and-the-private-sector-to-further-spaceexploration/2015/01/22/d022b34e-a24b-11e4-9f89-561284a573f8_story.html?utm_ term $=.91 \mathrm{a} 5087 \mathrm{f} 748 \mathrm{~b}$ 